\title{
Kegiatan ibadah pasien muslim selama menjalani perawatan di rumah sakit
}

\section{Religious practices of muslim patients during hospitalized}

\author{
Ruhyana* \\ ruhyana@unisayogya.ac.id* \\ Universitas 'Aisyiyah Yogyakarta, Indonesia \\ *corresponding author \\ Tanggal Submisi: 25 Agustus 2021, Tanggal Penerimaan: 30 Oktober 2021
}

\begin{abstract}
Abstrak
Keperawatan meyakini bahwa ibadah keagamaan penting dalam asuhan keperawatan holistik. Akan tetapi pelaksanaan kegiatan keagamaan masih sering diabaikan, dan penyakit membuat pasien kesulitan untuk dapat menjalankan ibadahnya. Penelitian ini dilakukan untuk menilai pelaksanaan ibadah pasienMuslim dan mengeksplorasi bagaimana pengalaman pasien melakukan ibadahnya sebelum dan selama menjalani perawatan di rumah sakit. Penelitian ini menggunakan metode deskriptif komparatif dengan desain potong lintang. Hasil penelitian menunjukkan bahwa untuk ibadah sunah selama menjalani perawatan terjadi penurunan dibandingkan sebelum perawatan. Sedangkan ibadah wajib "sholat" selalu dilakukan lima kali sehari baik sebelum maupun selama pasien manjelani perawatan.
\end{abstract}

Kata kunci: ibadah; pasien-muslim; perawatan

\begin{abstract}
Nursing recognizes that religious practices are essential to holistic care. However, the religious practices are often overlooked, and the illness made the patient has difficulty being able to carry out his religious worship. This study was to fully assess the religious practices of Muslim-patients and explore how the patient experience practicing the religious practices before and during confinement. This study made use of the descriptive comparative method by cross-sectional designs. Results show that the additional worship during confinement decreased was practiced compared to before confinement. While obligatory worship is always practiced five times a day even during confinement.
\end{abstract}

Keywords: religious practices; muslim-patients; hospitalized

\section{PENDAHULUAN}

Perspektif holistik dalam penanganan pasien dan integrasi agama serta dampaknya terhadap status kesehatan pasien sekarang banyak dibahas (Frisch \& Rabinowitsch, 2019). Secara khusus, hubungan antara praktik keagamaan dan kesehatan telah menjadi fokus perhatian yang signifikan (İMAMOĞLU, 2016). (Koenig, 2012) menambahkan bahwa adanya data yang menunjukkan 
kemungkinan praktik keagamaan yang diberikan dan manfaatnya terhadap kesehatan telah meningkat. Lebih lanjut (Litalien et al., 2021) menyatakan bahwa studi tentang hubungan antara agama dan kesehatan telah berkembang secara substansial dalam dekade terakhir. Sampai saat ini, beberapa temuan telah menunjukkan bahwa agama memiliki implikasi klinis (Kurnia, 2014) (Ismail et al., 2015). Agama penting bagi banyak pasien dan masalah agama mereka dapat ditangani dengan lebih baik di tempat layanan Kesehatan (Litalien et al., 2021).

Adanya masalah fisik, mental, maupun spiritual pasien tepat untuk menjadi perhatian bagi perawat, karena tugas perawat memberikan asuhan keperawatan yang komprehensif (Ismail et al., 2015). Hal ini sekaligus menunjukkan kembalinya pada fokus tradisional keperawatan, perhatian terhadap pasien secara menyeluruh atau perawatan holistic (Frisch \& Rabinowitsch, 2019). Istilah "holistik" dari bahasa Yunani "holos" yang berarti keseluruhan atau lengkap, adalah cara yang sangat tepat untuk menggambarkan tujuan perawatan untuk pasien (Jones, 2010) (Frisch \& Rabinowitsch, 2019). Bahkan studi agama dan kesehatan, serta integrasi agama ke dalam perawatan kesehatan, kemungkinan akan terus berkembang dan cara-cara baru untuk meneliti akan hal ini akan terus muncul (Saniotis, 2018). Hal ini terutama karena penelitian menunjukkan bahwa banyak pasien percaya agama memiliki peran yang penting dalam kehidupannya dan bahwa ada korelasi positif antara komitmen agama pasien dan satatus Kesehatan (Litalien et al., 2021). Tampaknya tubuh, pikiran, dan jiwa terhubung. Beberapa peneliti menunjukkan bahwa keyakinan positif, kenyamanan, dan kekuatan dari nilai-nilai agama, praktik keagamaan, dan do'a memberikan kontribusi pada proses penyembuhan pasien (Parenteau \& Wu, 2021).

Di Amerika Serikat, 90 persen pasien mengandalkan agama untuk kenyamanan atau kekuatan selama mengalami penyakitnya yang serius (Crompton, 2021). Perilaku coping religius yang dilakukan pasien meliputi berdoa, membaca inspirasi, berpartisipasi dalam ibadah, dan mencari dukungan dari pendeta atau anggota jemaat (Cagle et al., 2016). Dalam studi yang secara objektif meneliti perilaku ini dan hubungannya dengan status kesehatan, hubungan agama dan kesehatan sering ditemukan (Koenig, 2012). Oleh karena itu, penting untuk mengetahui bagaimana praktik keagamaan yang dilakukan oleh pasien selama menjalani perawatan (Abu-Ras \& Laird, 2011). Terlebih lagi karena sebagai pasien mereka memiliki keterbatasan karena penyakitnya, tentunya tidak dapat melakukannya praktek keagamaan-ibadahnya dengan sempurna seperti saat mereka sehat.

Perawat perlu mengetahui bagaimana pasien menjalankan praktik keagamaan-ibadahnya karena perawat perlu memberikan perhatian akan pentingnya memberikan asuhan pemenuhan kebutuhan religi pasien sebagai aspek vital asuhan keperawatan (Vincensi, 2019). Perawat dapat membantu dalam perjalanan religius pasien selama menjalani rawat inap di rumah sakit (Wardaningsih \& Junita, 2021). Perawat dapat memfasilitasi dan mendukung pencarian makna yang lebih dalam dalam iman (Frisch \& Rabinowitsch, 2019). Perawat menjadikan pasien sebagai manusia seutuhnya (Z, \& Avianti, 2017). Perawat sebagai bagian dari penyedia layanan kesehatan juga harus menyadari bagaimana keterlibatan agama dapat mempengaruhi gejala, kualitas hidup, dan kesediaan pasien untuk menerima implementasi keperawatan (Abu-Ras \& Laird, 2011). Perawat percaya bahwa kegiatan keagamaan dapat berfungsi sebagai bagian 
dari terapi (Kørup et al., 2021). Pada akhirnya peran perawat dalam membantu pemenuhan praktik keagamaan pasien akan meningkatkan kualitas proses keperawatan (Doufesh et al., 2014).

Akan menarik untuk mengkaji lebih lanjut tentang ibadah pasien selama masa perawatan di rumah sakit (Koenig \& Al Shohaib, 2014). Agama dan relevansinya dengan status kesehatan pasien juga penting untuk dianalisis oleh rumah sakit, terutama rumah sakit swasta yang dimiliki oleh lembaga keagamaan. Hasil penelitian yang telah dilakukan pada tahun 2002 oleh peneliti sendiri menunjukkan bahwa pasien cenderung memilih rumah sakit milik lembaga keagamaan. Salah satu alasan pasien adalah keyakinan pasien bahwa rumah sakit telah menyediakan dan memfasilitasi semua kebutuhan pasien yang berhubungan dengan ibadah mereka seperti sholat, mushola, dan lingkungan keagamaan. Berdasarkan hal tersebut, maka hal ini perlu mendapat perhatian dan studi lebih lanjut. Hasil penelitian ini akan sangat membantu dalam memvalidasi pentingnya praktik dan atau ibadah keagamaan dalam proses keperawatan. Penelitian ini bermaksud untuk mengetahui tentang praktik-ibadah keagamaan pasien di RS PKU Muhammadiyah sebagai salah satu rumah sakit milik lembaga keagamaan (Persyarikatan Muhammadiyah) di Daerah Istimewa Yogyakarta.

Tujuan umum penelitian ini adalah untuk secara utuh mengkaji ibadahpraktik keagamaan yang dilakukan pasien-responden selama menjalani perawatan di RS PKU Muhammadiyah. Studi ini mengeksplorasi bagaimana pengalaman pasien-responden melakukan ibadahnya sebelum dan selama menjalani perawatan di rumah sakit. Apakah ada perbedaan antara ibadah pasien-responden sebelum dan selama menjalani perawatan di rumah sakit?

\section{METODE}

Peneliti menggunakan metode penelitian deskriptif komparatif. Adapun pada penelitian ini dilakukan langkah-langkah untuk menilai dan mendeskripsikan pelaksanaan ibadah-praktik keagamaan pasien-responden, dan membandingkannya sebelum dan sesudah menjalani perawatan di RS PKU Muhammadiyah. Studi ini mengumpulkan informasi dengan mempergunakan instrumen penelitian berupa kuesioner, dengan desain cross-sectional. (Polit \& Beck, 2014) menyatakan bahwa desain cross-sectional adalah pengumpulan data pada satu titik waktu fenomena yang diteliti dikaji dalam satu waktu pengumpulan data.

Rumah Sakit PKU Muhammadiyah Yogyakarta tepat menjadi tempat untuk penelitian karena alasan berikut; rumah sakit swasta yang dimiliki oleh lembaga keagamaan Islam. Diakui sebagai rumah sakit terakreditasi penuh oleh Komite Akreditasi. Seperti diketahui, akreditasi merupakan salah satu parameter mutu rumah sakit. Rumah sakit ini juga sebagai rumah sakit pendidikan untuk mahasiswa ilmu kesehatan, kedokteran, keperawatan, kedokteran gigi, farmasi, dan manajemen rumah sakit. Memiliki tingkat hunian yang tinggi dan memberikan pelayanan kesehatan serta fasilitas penunjang medis yang mumpuni.

Responden atau subjek penelitian adalah pasien muslim yang dirawat inap di RS PKU Muhammadiyah yang menjalani rawat inap minimal tiga hari, pasien dewasa, laki-laki, dan perempuan, dengan berbagai jenis diagnosa medis. Pasien tidak dibedakan berdasarkan diagnosis medis. 
Metoda sampling yang dipilih pada penelitian adalah probability atau random sampling. Probability sampling melibatkan pemilihan secara acak dalam memilih responden. Ciri dari sampel probabilitas adalah peneliti dapat menentukan probabilitas bahwa setiap elemen populasi akan dimasukkan dalam sampel(Waltz et al., 2010). Pengambilan sampel acak melibatkan proses pemilihan di mana setiap elemen dalam populasi memiliki peluang yang sama dan independen untuk dipilih. Adapun ukuran sampel, menurut (Waltz et al., 2010) semakin besar sampel, semakin mewakili populasi. Sampel yang lebih kecil cenderung menghasilkan perkiraan yang kurang akurat daripada yang lebih besar. Penelitian ini mengacu pada rumus ukuran sampel Slovin. Total populasi terdiri dari 228 pasien Muslim. Dengan menggunakan rumus Slovin diperoleh total 54 responden.

Kuesioner berfungsi sebagai instrumen penelitian dalam penelitian ini. Secara umum, isi atau struktur kuesioner dibagi menjadi dua bagian. Bagian pertama dimaksudkan untuk memperoleh informasi tentang profil demografis peserta. Bagian kedua berisi beberapa pertanyaan yang dimaksudkan untuk menghasilkan data tentang pelaksanaan praktik keagamaan-ibadah passien. Beberapa pertanyaan tentang praktik keagamaan bervariasi sesuai dengan keyakinan Islam. Item pertanyaan yang termasuk dalam kuesioner didasarkan pada landasan teoritis dan data pra-survei. Pasien-responden dari pra-survei diminta untuk membuat daftar pengalaman praktik keagamaan mereka. Tanggapan responden kemudian dikumpulkan, dihitung, diringkas, dan dikelompokkan.

Praktik keagamaan pasien-responden diklasifikasikan berdasarkan praktik keagamaan sebelum dan selama perawatan. Mengenai topik kajian dalam kuesioner dilakukan review, revisi dan validasi oleh para ahli agama. Setelah kuesioner divalidasi, akhirnya digunakan sebagai instrumen pengumpulan data bagi responden penelitian ini. Peneliti menggunakan kuesioner, dan dengan instruksi yang sesuai, kemudian kuesioner ini disajikan kepada responden setelah mendapatkan persetujuan mereka untuk menjadi bagian dari responded penelitian. Ibadah-praktik keagamaan pasien-responden diklasifikasikan berdasarkan praktik keagamaan sebelum dan selama menjalani perawatan.

Peneliti menggunakan perlakuan statistik untuk menganalisis dan mencari hasil penelitian berdasarkan data yang dihasilkan dari pengukuran yang telah dilakukan. Metode statistik adalah analisis yang mewakili data statistik. Peneliti juga menggunakan perlakuan statistik untuk menerima atau menolak hipotesis nol yang telah ditetapkan. Statistik yang digunakan untuk penelitian ini meliputi distribusi frekuensi dan persentase, dan metode uji-T. Distribusi frekuensi dan persentase digunakan untuk mengidentifikasi jumlah observasi, profil demografi, dan praktik keagamaan pasien-responden. Uji-t sampel berpasangan digunakan dalam menggambarkan perbedaan antara dua sampel, yaitu untuk menguji perbedaan praktik keagamaan responden pasien sebelum dan selama perawatan. Setelah perhitungan nilai, kemudian diputuskan apakah menerima hipotesis atau tidak.

Salah satu prinsip etik yang paling mendasar dalam penelitian adalah setiap responden harus mendapatkan perlindungan dan jaminan privasi, terutama mengenai data yang diberikan oleh mereka. Ketika manusia digunakan sebagai studi, kerahasiaan harus dilakukan untuk memastikan bahwa hak-hak manusia tersebut dilindungi (Polit \& Beck, 2014) (Waltz et al., 2010). Semua pasien diundang untuk berpartisipasi tanpa paksaan dalam penelitian ini. Mereka diberi 
kesempatan untuk memilih atau menolak partisipasi dalam penelitian ini. Para pasien diberikan pernyataan informed consent yang telah disetujui oleh Rumah Sakit PKU Muhammadiyah. Penelitian ini merupakan penelitian deskriptif yang tidak lebih dari risiko minimal, ketidaknyamanan, bagi mereka yang berpartisipasi. Survei tidak mengumpulkan nama atau pengenal individu lainnya dan peneliti menjamin bahwa semua data yang diberikan oleh responden aman dan rahasia.

\section{HASIL DAN PEMBAHASAN}

Berdasarkan hasil penelitian yang telah dilakukan, didapatkan perolehan data distribusi frekuensi karakteristik responden berikut:

Tabel 1. Distribusi Frekuensi Demografi Pasien-Responden

\begin{tabular}{c|c|c}
\multirow{2}{*}{ Kelompok Umur } & \multicolumn{2}{|c}{ Jumlah } \\
\cline { 2 - 3 } & Frekuensi & Persentase \\
\hline $18-30$ & 9 & $17 \%$ \\
\hline $31-43$ & 19 & $35 \%$ \\
\hline $44-56$ & 17 & $31 \%$ \\
\hline $57-69$ & 7 & $13 \%$ \\
\hline $70-82$ & 2 & $4 \%$ \\
\hline Total & 54 & $100 \%$ \\
\hline Means of Ages $(\overline{\boldsymbol{X}})$ & 43.52 years old \\
\hline Jenis Kelamin & \multicolumn{2}{|c}{ Jumlah } \\
\hline Laki-laki & Frekuensi & Persentase \\
\hline Perempuan & 22 & $41 \%$ \\
\hline Total & 32 & $59 \%$ \\
\hline
\end{tabular}

\begin{tabular}{|c|c|c|}
\hline \multirow[t]{2}{*}{ Tingkat Pendidikan } & \multicolumn{2}{|c|}{ Jumlah } \\
\hline & Frekuensi & Persentase \\
\hline Sekolah Dasar & 0 & $0 \%$ \\
\hline Sekolah Menengah Pertama & 4 & $7 \%$ \\
\hline Sekolah Menengah Atas & 16 & $30 \%$ \\
\hline Diploma dan Sarjana & 30 & $56 \%$ \\
\hline Strata 2 & 4 & $7 \%$ \\
\hline Total & 54 & $100 \%$ \\
\hline \multirow[t]{2}{*}{ Status Perkawinan } & \multicolumn{2}{|c|}{ Jumlah } \\
\hline & Frekuensi & Persentase \\
\hline Single & 7 & $13 \%$ \\
\hline Bercerai-Berpisah & 4 & $7 \%$ \\
\hline Menikah & 41 & $76 \%$ \\
\hline Janda-Duda & 2 & $4 \%$ \\
\hline Total & 54 & $100 \%$ \\
\hline \multirow[t]{2}{*}{ Pekerjaan } & \multicolumn{2}{|c|}{ Jumlah } \\
\hline & Frekuensi & Persentase \\
\hline Pegawai Negeri Sipil & 16 & $30 \%$ \\
\hline Pegawai Swasta & 18 & $33 \%$ \\
\hline Wiraswasta & 9 & $17 \%$ \\
\hline Petani-Nelayan & 5 & $9 \%$ \\
\hline Belum-Tidak Bekerja & 6 & $11 \%$ \\
\hline Total & 54 & $100 \%$ \\
\hline \multirow[t]{2}{*}{ Pendapatan Keluarga } & \multicolumn{2}{|c|}{ Jumlah } \\
\hline & Frekuensi & Persentase \\
\hline
\end{tabular}




\begin{tabular}{|c|c|c|}
\hline Kurang dari Rp 2,000,000.00 & 6 & $11 \%$ \\
\hline $\mathrm{Rp} 2,000,000.00-\mathrm{Rp} 4,000,000.00$ & 26 & $48 \%$ \\
\hline Rp 4,000,000.00 - Rp 6,000,000.00 & 17 & $32 \%$ \\
\hline Lebih dari Rp 6,000,000.00 & 5 & $9 \%$ \\
\hline Total & 54 & $100 \%$ \\
\hline Rata-rata pendapatan keluarga $(\bar{x})$ & \multicolumn{2}{|c|}{$2,390,000.00$} \\
\hline \multirow[t]{2}{*}{ Jenis pembayaran RS } & \multicolumn{2}{|c|}{ Jumlah } \\
\hline & Frequency & Percentage \\
\hline Mandiri & 25 & $46 \%$ \\
\hline Sumbangan & 0 & $0 \%$ \\
\hline Asuransi & 29 & $54 \%$ \\
\hline Total & 54 & $100 \%$ \\
\hline \multirow[t]{2}{*}{ Gangguan Kesehatan } & \multicolumn{2}{|c|}{ Jumlah } \\
\hline & Frekuensi & Persentase \\
\hline Integument System & 2 & $4 \%$ \\
\hline Skeletal System & 1 & $2 \%$ \\
\hline Muscular System & 1 & $2 \%$ \\
\hline Nervous System & 1 & $2 \%$ \\
\hline Endocrine System & 6 & $11 \%$ \\
\hline Lymphatic System & 4 & $7 \%$ \\
\hline Cardiovascular System & 11 & $20 \%$ \\
\hline Respiratory System & 6 & $11 \%$ \\
\hline Digestive System & 9 & $17 \%$ \\
\hline Urinary System & 6 & $11 \%$ \\
\hline Reproductive System & 7 & $13 \%$ \\
\hline Total & 54 & $100 \%$ \\
\hline \multirow[t]{2}{*}{ Lama Perawatan } & \multicolumn{2}{|c|}{ Jumlah } \\
\hline & Frekuensi & Persentase \\
\hline 3-6 hari & 35 & $65 \%$ \\
\hline $7-12$ hari & 15 & $28 \%$ \\
\hline 13-18 hari & 4 & $7 \%$ \\
\hline Lebih dari 18 hari & 0 & $0 \%$ \\
\hline Total & 54 & $100 \%$ \\
\hline
\end{tabular}

Tabel 1 menunjukkan distribusi frekuensi dan persentase pasien-responden berdasarkan usianya. Ada 54 responden yang diikutsertakan dalam penelitian ini. Di antara jumlah responden, memiliki usia rata-rata 43,52 tahun dengan sebagian besar dalam kelompok usia 31-43 tahun (19 atau 35\%) dari responden. Dapat dilihat pada Tabel 1 bahwa pasien-responden tidak tersebar luas dalam rentang usia yang berbeda. Data ini menunjukkan bahwa adalah mungkin untuk memperoleh masalah kesehatan atau penyakit terlepas dari kelompok usia berapa saja. Dengan kata lain penyakit dapat terjadi pada semua tingkatan usia.

Adapun menurut jenis kelaminnya dari 54 pasien-responden, 22 atau $41 \%$ adalah laki-laki dan 32 atau 59\% adalah perempuan. Dapat diamati bahwa sebagian besar pasien-responden adalah perempuan. Data ini dapat didukung oleh (BPS, 2020) yang mempublikasikan bahwa jumlah penduduk perempuan lebih banyak dibandingkan dengan penduduk laki-laki. Lebih lanjut, dinas ini menyatakan bahwa rasio jenis kelamin penduduk pada skala nasional juga perempuan lebih banyak 
disbanding penduduk laki-laki. Adapun untuk penduduk perempuan di Daerah Istimewa Yogyakarta lebih tinggi 1 persen dibandingkan penduduk laki-laki.

Berdasarkan pencapaian pendidikannya, sebagian besar pasien-responden mencapai tingkat pendidikan perguruan tinggi, ini menyumbang 30 atau 56\% responden. Berdasarkan data yang ditemukan dalam tabel ini, lebih dari 50\% pasien-responden lulus dari perguruan tinggi. Hal ini dapat dikaitkan dengan lokasi penelitian karena kota Yogyakarta dikenal sebagai kota pelajar. Penduduknya relatif memiliki latar belakang pendidikan yang lebih tinggi dibandingkan dengan daerah lainnya. Terdapat ratusan universitas dan sekolah yang berada di dalam batas wilayahnya (BPS, 2019). Menurut status perkawinannya diantara semua pasien-responden 7 atau 13\% adalah lajang, 4 atau $7 \%$ bercerai/berpisah, 41 atau $76 \%$ menikah dan 2 atau $4 \%$ janda.

Sebagian besar responden dengan total 18 atau 33\% bekerja di lembaga swasta. Meskipun hanya ada sedikit perbedaan dibandingkan dengan pegawai pemerintah yang berjumlah 16 atau $30 \%$. Dalam penelitian ini, responden yang menganggur mengacu pada mereka yang sedang menempuh pendidikan dan lanjut usia yang sudah pensiun. Data yang terdapat dalam tabel ini lebih lanjut didukung oleh informasi yang dirilis oleh (BPS, 2019) yang menunjukkan bahwa tingkat pengangguran adalah 8,14 dan didistribusikan di antara kelompok usia termuda dan tua dalam populasi. Dapat dicatat bahwa ada banyak responden yang diklasifikasikan dalam pekerjaan swasta. Hal ini dapat didukung lebih lanjut oleh data relevan lainnya yang dirilis oleh (BPS, 2019) yang menunjukkan bahwa sebagian besar distribusi tenaga kerja di Indonesia terkonsentrasi pada sektor swasta seperti pertanian, kehutanan, perburuan, dan perikanan (BPS, 2019).

Standar pendapatan keluarga mengacu pada pendapatan yang berlaku di Yogyakarta yang dirilis oleh Badan Pusat Statistik. Terlihat dari data bahwa sebagian besar responden yang berjumlah 26 atau $48 \%$ termasuk dalam golongan pendapatan $\mathrm{Rp}$ 2.000.000-4.000.000. Sedangkan pendapatan keluarga rata-rata adalah Rp 2.390.000. Cara pembayaran responden pasien adalah 29 atau 54\% membayar melalui asuransi sedangkan 25 atau $46 \%$ dengan pembayaran sendiri.

Diagnosis medis didasarkan pada rekam medis pasien dan dikelompokkan oleh peneliti sesuai dengan sistem tubuh yang terlibat dalam proses penyakit. Sebagian besar diagnosis medis melibatkan sistem kardiovaskular dengan jumlah 11 atau $20 \%$, diikuti oleh penyakit pada sistem pencernaan dengan 9 atau $17 \%$ dan gangguan sistem reproduksi 7 atau 13\%. Temuan yang dikemukakan dapat didukung oleh data dari Dinas Kesehatan Daerah Istimewa Yogyakarta (2019) bahwa pola 10 besar penyakit berdasarkan survailance terpadu penyakit Puskesmas menunjukkan bahwa masalah kardiovaskular dan pencernaan merupakan jenis penyakit yang memiliki angka kejadian yang tinggi, dan menempati urutan pertama dan kedua.

Sebagian besar responden menjalani perawatan selama durasi tiga sampai enam hari, 35 atau $65 \%$. Hanya sebagian kecil pasien-responden yang menjalani perawatan lebih dari enam hari. Data yang disajikan dapat dikaitkan dengan (Darmawan et al., 2020) yang menyatakan bahwa salah satu kecenderungan kebijakan rumah sakit adalah meminimalkan lama rawat inap pasien, sehingga lama rawat inap mengalami penurunan setiap tahunnya. (Darmawan et al., 2020) menunjukan data pada salah satu rumah sakit pada tahun 2015 lama rawat inap 3,16 hari dan terdapat kecenderungan menurun pada tahun 2018 yaitu 2,28 hari. Hasil 
wawancara dengan pihak rumah sakit menunjukkan bahwa LOS yang rendah disebabkan kebijakan batas waktu peserta BPJS dan kasus pelayanan persalinan tanpa operasi, yang kemudian menjadi rujukan rumah sakit dalam pembuatan kebijakan. Kebijakan ini terkait dengan pembiayaan rumah sakit, dimana lamanya pasien dirawat di rumah sakit berdampak pada anggaran rumah sakit. Ketika pasien dan keluarga tinggal lama di rumah sakit, mereka akan menghabiskan sumber daya rumah sakit seperti air, listrik, dan lainnya. Pada akhirnya akan meningkatkan biaya operasional rumah sakit. Namun, di sisi lain, pada pasien yang memiliki penyakit parah atau kronis menjalani masa perawatan yang lebih lama.

Tabel 2. Distribusi Frekuensi Praktek Ibadah Pasien-Responden

Sebelum Perawatan di Rumah Sakit

\begin{tabular}{|c|c|c|c|c|c|c|c|c|c|c|c|c|}
\hline \multirow{3}{*}{$\begin{array}{c}\text { Ibadah } \\
\text { Keagamaan }\end{array}$} & \multicolumn{2}{|c|}{ Selalu } & \multicolumn{2}{|c|}{ Sering } & \multicolumn{2}{|c|}{$\begin{array}{l}\text { Kadang- } \\
\text { kadang }\end{array}$} & \multicolumn{2}{|c|}{ Jarang } & \multicolumn{2}{|c|}{$\begin{array}{l}\text { Tidak } \\
\text { Pernah }\end{array}$} & \multirow{2}{*}{\multicolumn{2}{|c|}{ Interpretasi }} \\
\hline & \multicolumn{2}{|c|}{5} & \multicolumn{2}{|c|}{4} & \multicolumn{2}{|c|}{3} & \multicolumn{2}{|c|}{2} & \multicolumn{2}{|c|}{1} & & \\
\hline & $\mathrm{F}$ & $\%$ & $\mathrm{f}$ & $\%$ & $\mathrm{f}$ & $\%$ & $\mathrm{f}$ & $\%$ & $\mathrm{~F}$ & $\%$ & $\begin{array}{c}\text { Rata- } \\
\text { rata }\end{array}$ & $\begin{array}{c}\text { Kategori } \\
\text { Tanggapan }\end{array}$ \\
\hline $\begin{array}{l}\text { Melakukan sholat } \\
\text { fardhu setiap hari }\end{array}$ & 54 & 100 & - & - & - & - & - & - & - & - & 5.00 & $\begin{array}{c}\text { Selalu } \\
\text { dilakukan }\end{array}$ \\
\hline $\begin{array}{l}\text { Melakukan sholat lail } \\
\text { setiap malam }\end{array}$ & 20 & 37 & 10 & 18 & 9 & 17 & 9 & 17 & 6 & 11 & 3.54 & $\begin{array}{c}\text { Kadang } \\
\text { dilakukan }\end{array}$ \\
\hline $\begin{array}{l}\text { Melakukan sholat sunah } \\
\text { rawatib }\end{array}$ & 30 & 56 & 16 & 29 & 6 & 11 & 2 & 4 & - & - & 4.37 & $\begin{array}{c}\text { Selalu } \\
\text { dilakukan }\end{array}$ \\
\hline Membaca Al Qur'an & 13 & 24 & 17 & 31.5 & 17 & 31.5 & 7 & 13 & - & - & 3.67 & $\begin{array}{c}\text { Kadang } \\
\text { dilakukan }\end{array}$ \\
\hline $\begin{array}{ll}\text { Melakukan } & \text { Puasa } \\
\text { Ramadan } & \\
\end{array}$ & 54 & 100 & - & - & - & - & - & - & - & - & 5.00 & $\begin{array}{c}\text { Selalu } \\
\text { dilakukan }\end{array}$ \\
\hline $\begin{array}{l}\text { Melakukan puasa Sunah } \\
\text { setiap senin dan kamis }\end{array}$ & 10 & 19 & 3 & 6 & 18 & 33 & 18 & 33 & 5 & 9 & 2.91 & Dilakukan \\
\hline Menghadiri pengajian & 5 & 9 & 8 & 15 & 22 & 41 & 15 & 28 & 4 & 7 & 2.91 & Dilakukan \\
\hline $\begin{array}{l}\text { Membayar zakat \& } \\
\text { shodakoh }\end{array}$ & 54 & 100 & - & - & - & - & - & - & - & - & 5.00 & $\begin{array}{c}\text { Selalu } \\
\text { dilakukan }\end{array}$ \\
\hline $\begin{array}{l}\text { Melakukan sholat jumat } \\
\text { (bagi laki-laki) }\end{array}$ & 22 & 100 & - & - & - & - & - & - & - & - & 5.00 & $\begin{array}{c}\text { Selalu } \\
\text { dilakukan }\end{array}$ \\
\hline
\end{tabular}

Tabel 3. Distribusi Frekuensi Praktek Ibadah Pasien-Responden

Selama Perawatan di Rumah Sakit

\begin{tabular}{|c|c|c|c|c|c|c|c|c|c|c|c|c|}
\hline \multirow{3}{*}{$\begin{array}{l}\text { Religious } \\
\text { Practices }\end{array}$} & \multicolumn{2}{|c|}{ Always } & \multicolumn{2}{|c|}{ Often } & \multicolumn{2}{|c|}{$\begin{array}{l}\text { Occasi } \\
\text { onally }\end{array}$} & \multicolumn{2}{|c|}{ Seldom } & \multicolumn{2}{|c|}{ Never } & \multicolumn{2}{|c|}{ Interpretation } \\
\hline & \multicolumn{2}{|c|}{5} & \multicolumn{2}{|c|}{4} & \multicolumn{2}{|c|}{3} & \multicolumn{2}{|c|}{2} & \multicolumn{2}{|c|}{1} & & \\
\hline & $\mathrm{F}$ & $\%$ & f & $\%$ & $f$ & $\%$ & $f$ & $\%$ & $f$ & $\%$ & Mean & $\begin{array}{l}\text { Response } \\
\text { Category }\end{array}$ \\
\hline $\begin{array}{l}\text { Melakukan sholat } \\
\text { fardhu setiap hari }\end{array}$ & 54 & 100 & - & - & - & - & - & - & - & - & 5.00 & $\begin{array}{c}\text { Selalu } \\
\text { dilakukan }\end{array}$ \\
\hline $\begin{array}{l}\text { Melakukan sholat lail } \\
\text { setiap malam }\end{array}$ & - & - & 1 & 2 & - & - & 15 & 28 & 38 & 70 & 1.33 & $\begin{array}{c}\text { Jarang } \\
\text { dilakukan }\end{array}$ \\
\hline $\begin{array}{l}\text { Melakukan sholat sunah } \\
\text { rawatib }\end{array}$ & - & - & 2 & 4 & 7 & 13 & 8 & 15 & 37 & 68 & 1.52 & $\begin{array}{c}\text { Jarang } \\
\text { dilakukan }\end{array}$ \\
\hline Membaca Al Qur'an & 2 & 4 & 7 & 13 & 20 & 37 & 4 & 7 & 21 & 39 & 2.35 & Practiced \\
\hline $\begin{array}{l}\text { Mendengarkan } \\
\text { pengajian selama di RS }\end{array}$ & - & - & 5 & 9 & 16 & 30 & 8 & 15 & 25 & 46 & 2.00 & $\begin{array}{c}\text { Jarang } \\
\text { dilakukan } \\
\end{array}$ \\
\hline $\begin{array}{ll}\text { Berdoa } & \text { untuk } \\
\text { kesembuhan } & \\
\end{array}$ & 37 & 69 & - & - & - & - & - & - & 17 & 35 & 3.74 & $\begin{array}{c}\text { Kadang } \\
\text { dilakukan }\end{array}$ \\
\hline $\begin{array}{l}\text { Meminta orang lain } \\
\text { mendoakan } \\
\text { kesembuhan pasien }\end{array}$ & 54 & 100 & - & - & - & - & - & - & - & - & 5.00 & $\begin{array}{c}\text { Selalu } \\
\text { dilakukan }\end{array}$ \\
\hline
\end{tabular}


Tabel 4. Perbedaan Praktek Ibadah Pasien-Responden Sebelum dan Selama

Perawatan di Rumah Sakit

\begin{tabular}{l|c|l|c|l}
\multirow{2}{*}{ Religious Practices } & \multicolumn{3}{c}{ Before Confinement } & \multicolumn{2}{c}{ During Confinement } \\
\cline { 2 - 5 } & $\overline{\bar{X}}$ & Response Category & $\bar{X}$ & \multicolumn{1}{c}{ Response Category } \\
\hline Sholat Fardhu & 5.00 & Selalu dilakukan & 5.00 & Selalu dilakukan \\
\hline Sholat Rawatib & 4.37 & Selalu dilakukan & 1.52 & Jarang dilakukan \\
\hline Sholat Lail & 3.54 & Kadang dilakukan & 1.33 & Jarang dilakukan \\
\hline Membaca Al Qur'an & 3.67 & Kadang dilakukan & 2.35 & Dilakukan \\
\hline Pengajian & 2.91 & Dilakukan & 2.00 & Dilakukan
\end{tabular}

Tabel 4 menunjukkan perbedaan antara ibadah-praktik keagamaan pasienresponden sebelum dan selama perawatan di rumah sakit. Ada lima amalan ibadah yang dilakukan oleh pasien-responden sebelum dan selama perawatan yang dibandingkan, yaitu, sholat fardhu, sholat rawatib, sholat lail, membaca Al Qur'an, dan kegiatan taklim pengajian.

Dalam penelitian saat ini, praktik keagamaan-ibadah yang hanya dilakukan pada acara-acara khusus tidak dibandingkan. Contoh amalan tersebut antara lain sebagai berikut; puasa ramadhan yang hanya dilakukan selama bulan ramadhan; zakat hanya diberikan setahun sekali pada akhir bulan ramadhan; puasa sunah sebagai puasa tambhan yang tidak dianjurkan dan boleh tidak dilakukan bagi umat Islam yang sakit; sedangkan sholat jum'at dapat digantikan sholat fardhu bagi umat Islam laki-laki yang tidak dapat menunaikannya dengan alasan musafir atau sakit.

Tabel 5. Paired Samples Statistics Ibadah Pasien-Responden Sebelum dan Selama Perawatan di Rumah Sakit

\begin{tabular}{|c|c|c|c|c|c|}
\hline & Religious Practices & Mean & $\mathbf{N}$ & $\begin{array}{c}\text { Std. } \\
\text { Deviation }\end{array}$ & Std. Error Mean \\
\hline \multirow{2}{*}{$\begin{array}{c}\text { Pair } \\
1\end{array}$} & Sholat Fardhu & $5.00^{\mathrm{a}}$ & 54 & .000 & .000 \\
\hline & Performed Sholat Fardhu & $5.00^{\mathrm{a}}$ & 54 & .000 & .000 \\
\hline \multirow{2}{*}{$\begin{array}{c}\text { Pair } \\
2\end{array}$} & Sholat Lail & 3.54 & 54 & 1.424 & .194 \\
\hline & Performed Sholat Lail & 1.33 & 54 & .583 & .079 \\
\hline \multirow{2}{*}{$\begin{array}{c}\text { Pair } \\
3 \\
\end{array}$} & Sholat Rawatib & 4.37 & 54 & .831 & .113 \\
\hline & Performed Sholat Rawatib & 1.52 & 54 & .863 & .117 \\
\hline \multirow{2}{*}{$\begin{array}{c}\text { Pair } \\
4 \\
\end{array}$} & Recite Quran & 3.67 & 54 & .991 & .135 \\
\hline & Recited Quran & 2.35 & 54 & 1.231 & .168 \\
\hline \multirow{2}{*}{$\begin{array}{c}\text { Pair } \\
5\end{array}$} & Participate Pengajian & 2.91 & 54 & 1.051 & .143 \\
\hline & $\begin{array}{l}\text { Listened to Pengajian in the } \\
\text { Hospital }\end{array}$ & 2.02 & 54 & 1.073 & .146 \\
\hline
\end{tabular}

a. The correlation and $t$ cannot be computed because the standard error of the difference is 0 . 
Tabel 6. Paired Samples Test Ibadah Pasien-Responden Sebelum dan Selama Perawatan di Rumah Sakit

\begin{tabular}{|c|c|c|c|c|c|c|c|c|c|}
\hline & & \multicolumn{5}{|c|}{ Paired Differences } & \multirow[t]{3}{*}{$\mathbf{t}$} & \multirow[t]{3}{*}{ df } & \multirow{3}{*}{$\begin{array}{l}\text { Sig. } \\
\text { (2- } \\
\text { taile } \\
\text { d) }\end{array}$} \\
\hline & \multirow[t]{2}{*}{ Religious Practices } & \multirow{3}{*}{$\begin{array}{l}\text { Mean } \\
2.204\end{array}$} & \multirow{3}{*}{$\begin{array}{c}\begin{array}{c}\text { Std. } \\
\text { Deviati } \\
\text { on }\end{array} \\
1.294\end{array}$} & \multirow{3}{*}{\begin{tabular}{|c|}
$\begin{array}{c}\text { Std. } \\
\text { Error } \\
\text { Mean }\end{array}$ \\
.176
\end{tabular}} & \multicolumn{2}{|c|}{$\begin{array}{l}\text { 95\% Confidence } \\
\text { Interval of the } \\
\text { Difference }\end{array}$} & & & \\
\hline & & & & & \multirow{2}{*}{$\begin{array}{l}\text { Lower } \\
1.850\end{array}$} & \multirow{2}{*}{$\begin{array}{l}\text { Upper } \\
2.557\end{array}$} & & & \\
\hline $\begin{array}{c}\text { Pair } \\
2\end{array}$ & $\begin{array}{c}\text { Sholat Lail - Performed Sholat } \\
\text { Lail }\end{array}$ & & & & & & $\begin{array}{c}12.51 \\
4\end{array}$ & 53 & .000 \\
\hline $\begin{array}{c}\text { Pair } \\
3\end{array}$ & $\begin{array}{c}\text { Sholat Rawatib - Performed } \\
\text { Sholat Rawatib }\end{array}$ & 2.852 & 1.017 & .138 & 2.574 & 3.129 & $\begin{array}{c}20.60 \\
7\end{array}$ & 53 & .000 \\
\hline $\begin{array}{c}\text { Pair } \\
4 \\
\end{array}$ & Recite Quran - Recited Quran & 1.315 & .843 & .115 & 1.085 & 1.545 & $\begin{array}{c}11.46 \\
4 \\
\end{array}$ & 53 & .000 \\
\hline $\begin{array}{c}\text { Pair } \\
5\end{array}$ & $\begin{array}{l}\text { ParticipatePengajian - Listened } \\
\text { Pengajian in the Hospital }\end{array}$ & .889 & 1.284 & .175 & .539 & 1.239 & 5.089 & 53 & .000 \\
\hline
\end{tabular}

Statistik deskriptif untuk semua variabel ditunjukkan pada Tabel 5 (Statistik Sampel Berpasangan) dan Tabel 6 (Uji Sampel Berpasangan). Sholat fardhu yang dipraktikkan oleh pasien-responden sebelum perawatan memiliki rata-rata $(=5,00)$ dan dikategorikan "Selalu Dilakukan", sedangkan selama perawatan juga rata-rata $(=5,00)$ dikategorikan "Selalu Dilakukan".

Secara statistik, hal ini tidak dapat dianalisis karena kesalahan baku perbedaannya adalah 0 . Namun demikian, data yang menunjukan tidak adanya perbedaan sebelum dan selama menjalani perawatan di rumah sakit ini dapat diartikan bahwa tidak ada perbedaan dalam praktik keagamaan (sholat fardhu). Dengan kata lain, sholat fardhu selalu dipraktikkan oleh pasien-responden lima kali sehari, sebelum dan selama perawatan. Ada banyak alasan mengapa seorang pasien Muslim selalu menunaikan shalat baik sebelum maupun selama menjalani perawatan. Ini juga merupakan bukti tingkat keimanan mereka yang baik. Muslim bukan hanya mengetahui sholat adalah kewajiban baginya yang harus dilakukan apapun kondisi yang dialaminya.

Memang ada konsep rukhsah bagi mereka yang tidak dapat mememenuhi rukun dan ketentuan ibadah secara sempurna karena uzur atau keterbatasan lain yang dialami seorang muslim. Rukhsah adalah hukum yang datang perihal sebuah perbuatan karena uzur tertentu sebagai pengecualian seperti pada musafir, orang lanjut usia, atau sakit. Pembatalan puasa bagi musafir di bulan ramadhan, pembatalan puasa ramadhan bagi orang sakit memang bisa dilakukan, namun sholat fardhu sebagai ibadah wajib harus dilakukan selama seorang muslim masih hidup.

Seperti yang disebutkan dalam taabel 5, baik sebelum maupun selama perawatan pasien-responden Muslim selalu mempraktekkan sholat fardhu. Sholat fardhu adalah kewajiban utama bagi umat Islam. Tidak ada alasan untuk meninggalkan sholat bahkan bagi kaum muslimin yang sedang sakit. Dijelaskan pula, bagi umat Islam yang sakit diberikan keringanan untuk menunaikan shalat dengan cara menggabungkan dua shalat dalam satu waktu (jama) atau memperpendek rakaat (qosor). Dalam hal pasien tidak dapat berdiri, umat Islam diperbolehkan untuk berlatih dengan duduk atau berbaring di tempat tidur. Pada prinsipnya seorang Muslim yang sakit tetap berkewajiban melakukan sholat. Namun karena adanya keterbatasan secara fisik, dia mendapatkan beberapa keringanan. Adapun bentuk-bentuk keringanan sholat ada beberapa prinsip yang 
harus diperhatikan; sakit tidak menggugurkan kewajiban sholat, dia dapat melakukan sesuai denga napa yang bisa dilakukannya. Muslim yang sakit tetap memiliki kewajiban untuk mendirikan sholat. Melakukan dengan gerakan dan posisi-posisi sholat semampu yang bisa dilakukan, meskipun tidak sampai sempurna. Secara prinsip, apapun gerakan dan bacaan pada saat sholat yang masih bisa untuk dialakukan, maka tetap wajib harus dikerjakan. Adapun saat sudah tidak mungkin lagi untuk dilakukan, barulah boleh untuk ditinggalkan.

Beberapa keringanan yang ada terkait Muslim yang sakit diantaranya, wudhu atau mandi janabah yang bisa digantikan dengan bertayamum. Saat sholat tidak bisa berdiri maka boleh sambil duduk atau kalua duduk juga tidak bisa dilakukan maka dia bisa sambal berbaring. Keringanan terkait sholat yang lainnya adalah bisa tidak menghadap ke kiblat apabila tidak memungkinkan. Karena terkait dengan kondisi sakitnya maka sholat juga tidak berkewajiban dilakukan secara berjamah. Begitupun bagi Muslim laki-laki kewajiban sholat Jumat dapat digantikan dengan sholat fardu dhuhur.

Shalat dalam Islam memiliki kedudukan penting dan utama. Seorang muslim tidak diperkenankan melalaikan sholat terlebih meninggalkannya dalam situasi dan keadaaan apapun. Sakit tidak dapat dijadikan alas an untuk tidak melakukan shalat. Tidak boleh seorang Muslim melalaikan shalat wajib sampai keluar dari waktunya meskipun dia dalam kondisi sakit selama akalnya masih sehat. Bahkan semestinya Muslim ketika kondisi sakit lebih bersemangat untuk melakukan shalat dari pada ketika kondisi sehat. Hendaknya seorang Muslim tetap menunaikan shalat tepat waktu walaupun ada keterbatasan dalam menyempurnakan syarat-syarat sholat yang lainnya.

Adapun kalau kita lihat hasil uji statistic pada ibadah sunah, karena semua nilai $\mathrm{p}(0,00)$ lebih rendah dari tingkat signifikansi 0,05 , maka hipotesis nol yang diuji semuanya ditolak. Hal ini berarti ada perbedaan yang signifikan antara (sholat lail, sholat rawatib, membaca Al Quran, pengajian) sebelum dan selama dikandung. Lebih lanjut hal ini dapat dimaknai adanya ppenurunan kegiatan ibadah selama menjalani perawatan dibandingkan sebelum menjalani perawatan di rumah sakit.

Hasil nilai statistik memperkuat ibadah dalam Islam secara umum dibagi menjadi dua kelompok ibadah; wajib (fardhu) dan ibadah tambahan (sunnah) (Kadun \& Zaly, 2020). Ibadah wajib tidak boleh ditinggalkan dalam kondisi apapun, bahkan ketika umat Islam sedang sakit. menambahkan bahwa ibadah wajib harus dilakukan dan tidak boleh ditinggalkan. Dengan kata lain, ibadah wajib disebut sebagai tiang agama dan juga dikatakan sebagai pembeda antara Muslim dan non-Muslim.

Misalnya, salah satu ibadah wajib adalah sholat fardu, sehingga pasienpasien Muslim selalu mempraktikkan sholat sebelum dan selama perawatan. Selain itu, umat Islam juga meyakini bahwa sholat tidak hanya sekedar menunaikan kewajiban sebagai seorang muslim, tetapi juga terdapat 'hikmah' (kebijaksanaan) di balik 'sholat' (Zaly, 2020) Di sisi lain, 'sholat' juga merupakan penyerahan diri kepada Allah bagi umat Islam yang sakit (Kadun \& Zaly, 2020).

Sedangkan ibadah sunnah (tambahan) dianjurkan untuk diamalkan atau tidak boleh dilakukan oleh umat Islam jika memiliki masalah seperti sakit (Kurniati, 2017). Ibadah ini bertujuan sebagai pelengkap ibadah wajib yang dilakukan oleh umat Islam (Abu-Ras \& Laird, 2011). Sebagaimana dilihat pada tabel bahwa sholat lail, sholat rawatib, pengajian dan membaca Al-Qur'an adalah ibadah tambahan atau 
sunah, terkait dengan kondisi kesehatan mereka; Umat Islam mengutamakan ibadah wajib dan mengurangi ibadah tambahan (Kurniawan, 2018) (Darmawan et al., 2020). Seperti yang diungkapkan oleh (Kadun \& Zaly, 2020), beberapa pasien mengalami penurunan aktivitas, bahkan aktivitas ibadah jika mereka menjalani perawatan di rumah sakit.

Namun perlu diperhatikan bagi perawat, pasien, dan keluarga, bila pasien dirawat di rumah sakit dengan baik, melaksanakan beberapa ibadah bahkan ibadah dengan kategori tambahan (sunah) adalah mungkin untuk dilakukan, dan hal ini akan lebih baik dilakukan untuk mendukung upaya kesembuhannya $(\mathrm{H}$. Hairillah, 2015). Dimana apabila semuanya dipraktekkan, semua ibadah itu akan membuat pasien secara psikologis lebih tenang, lebih menahan rasa sakit, dan situasi ini akan sangat bermanfaat bagi pasien (Murtiningsih \& Zaly, 2020). Pasien hanya membutuhkan motivasi untuk menunaikan ibadah. Semua tindakan yang dilakukan oleh seseorang memiliki motivasi, dan motivasi yang kuat akan mengatasi segala hambatan (Herawanti et al., 2013). Selain itu, Islam juga mengajarkan bahwa segala perbuatan (khususnya ibadah) bergantung pada niat (motivasi). Ketika umat Islam memiliki niat, keinginan yang kuat, dan keikhlasan dalam menjalankan ibadah, maka umat Islam akan dapat melakukannya dengan baik tanpa kendala (Warto, 2019).

\section{SIMPULAN}

Pasien senantiasa melakukan ibadah wajib. Sholat fardhu sebagai ibadah yang wajib dilakukan bagi muslim selalu dipraktikkan lima kali sehari baik sebelum maupun selama perawatan di rumah sakit. Adapun ibadah lainya yang termasuk ibadah sunah; sholat lail, sholat rawatib, membaca Al Quran, dan pengajian selama dirawat mengalami penurunan dibandingkan sebelum dirawat di rumah sakit.

Berdasarkan temuan dan simpulan penelitian, peneliti merekomendasikan kepada pasien, untuk selalu melakukan "ibadah-praktik keagamaan" selama dirawat di rumah sakit meskipun mereka mungkin memiliki keterbatasan. Pasien dapat meminta perawat, dan atau Bina Rohani Islam, untuk membantu dan mengatasi keterbatasan mereka dalam melakukan ibadahnya. Bagi rumah sakit, peneliti merekomendasikan agar hasil penelitian ini dapat dijadikan acuan tambahan bagi pengambil keputusan untuk meningkatkan kualitas layanan rumah sakit.

\section{DAFTAR PUSTAKA}

Abu-Ras, W., \& Laird, L. (2011). How Muslim and Non-Muslim Chaplains Serve Muslim Patients? Does the Interfaith Chaplaincy Model have Room for Muslims' Experiences? Journal of Religion and Health, 50(1), 46-61. https://doi.org/10.1007/s10943-010-9357-4

BPS. (2019). Statistik Pendapatan Februari 2019. 175-1, $\square$. https://www.bps.go.id/publication/2019/05/31/4f7829e7743f9dfbd498577e/s tatistik-pendapatan-februari-2019.html

BPS. (2020). Katalog BPS: 2104010. 
Cagle, J. G., LaMantia, M. A., Williams, S. W., Pek, J., \& Edwards, L. J. (2016). Predictors of Preference for Hospice Care Among Diverse Older Adults. American Journal of Hospice and Palliative Medicine, 33(6), 574-584. https://doi.org/10.1177/1049909115593936

Crompton, M. (2021). Religion in everyday life. Children, Spirituality, Religion and Social Work, 95-100. https://doi.org/10.4324/9781315260525-15

Darmawan, D., Miharja, D., Waluyajati, R. S. R., \& Isnaeniah, E. (2020). Sikap Keberagamaan Masyarakat Menghadapi Wabah COVID-19. Religious: Jurnal Studi Agama-Agama Dan Lintas Budaya, 4(2), 115-124. https://doi.org/10.15575/rjsalb.v4i2.8596

Doufesh, H., Ibrahim, F., Ismail, N. A., \& Wan Ahmad, W. A. (2014). Effect of Muslim Prayer (Salat) on $\alpha$ Electroencephalography and Its Relationship with Autonomic Nervous System Activity. Journal of Alternative and Complementary Medicine, 20(7), 558-562. https://doi.org/10.1089/acm.2013.0426

Frisch, N. C., \& Rabinowitsch, D. (2019). What's in a Definition? Holistic Nursing, Integrative Health Care, and Integrative Nursing: Report of an Integrated Literature Review. Journal of Holistic Nursing, 37(3), 260-272. https://doi.org/10.1177/0898010119860685

H. Hairillah. (2015). Kedudukan As-Sunnah Dan Tantangannya Dalam Hal Aktualisasi Hukum Islam. Mazahib, Vol. XIV,(1-20), 193.

Herawanti, Y., Sukamto, E., \& Milkhatun. (2013). Studi Deskriptif Pengetahuan Klien Tentang Tata Cara Salat Selama Rawat Inap Dalam Pemenuhan Kebutuhan Spiritual. Husada Mahakam: Jurnal Kesehatan, 3(5), 219-231.

İMAMOĞLU, O. (2016). Benefits of Prayer as a Physical Activity. International Journal of Science Culture and Sport, 4(17), 306-306. https://doi.org/10.14486/intjscs559

Ismail, S., Hatthakit, U., \& Chinawong, T. (2015). Caring Science within Islamic Contexts: A Literature Review. Nurse Media Journal of Nursing, 5(1), 34. https://doi.org/10.14710/nmjn.v5i1.10189

Jones, T. L. (2010). A holistic framework for nursing time: implications for theory, practice, and research. Nursing Forum, 45(3), 185-196. https://doi.org/10.1111/j.1744-6198.2010.00180.x

Kadun, M., \& Zaly, N. W. (2020). Gambaran Praktek Ibadah Sholat Pasien Yang Dirawat Dirumah Sakit X. Journal of Islamic Nursing, 5(1), 48. https://doi.org/10.24252/join.v5i1.10843

Koenig, H. G. (2012). Religion, Spirituality, and Health: The Research and Clinical Implications. ISRN Psychiatry, 2012, 1-33. 
https://doi.org/10.5402/2012/278730

Koenig, H. G., \& Al Shohaib, S. (2014). Health and well-being in Islamic societies: Background, research, and applications. Health and Well-Being in Islamic Societies: Background, Research, and Applications, 9783319058733, 1-361. https://doi.org/10.1007/978-3-319-05873-3

Kørup, A. K., Søndergaard, J., Alyousefi, N. A., Lucchetti, G., Baumann, K., Lee, E., Karimah, A., Ramakrishnan, P., Frick, E., Büssing, A., Schouten, E., Butcher, W., Hefti, R., Wermuth, I., \& Hvidt, N. C. (2021). The International NERSH Data Pool of Health Professionals' Attitudes Toward Religiosity and Spirituality in 12 Countries. Journal of Religion and Health, 60(1), 596-619. https://doi.org/10.1007/s10943-020-01077-6

Kurnia, D. (2014). Hubungan antara Spiritual Well Being dengan Coping pada Musyrifah Ma'had Sunan Ampel Al-'Aly (MSAA) Universitas Islam Negeri (UIN) Maulana Malik Ibrahim Malang. Psikoislamika: Jurnal Psikologi Dan Psikologi Islam, 11(1), 20-52. https://doi.org/10.18860/psi.v11i1.6380

Kurniati, V. (2017). Halaman 1 dari 67 muka | daftar isi. 1-35.

Kurniawan, A. (2018). DAHSYATNYA SHALAT SUNNAH TAHAJJUD DAN DHUHA PERSPEKTIF YUSUF MANSUR Skripsi. Skripsi, 46.

Litalien, M., Atari, D. O., \& Obasi, I. (2021). The Influence of Religiosity and Spirituality on Health in Canada: A Systematic Literature Review. In Journal of Religion and Health (Issue 0123456789). Springer US. https://doi.org/10.1007/s10943-020-01148-8

Parenteau, S. C., \& Wu, H. (2021). Religious Problem-Solving Styles and Life Satisfaction: Exploring God, the Will and the Way. Journal of Religion and Health, 60(6), 4451-4466. https://doi.org/10.1007/s10943-020-01159-5

Polit, D. F., \& Beck, C. T. (2014). Essentials of Nursing Research Seventh Edition Appraising Evidence for Nursing Practice. In Lippincott Williams \& Wilkins.

Saniotis, A. (2018). Understanding Mind/Body Medicine from Muslim Religious Practices of Salat and Dhikr. Journal of Religion and Health, 57(3), 849-857. https://doi.org/10.1007/s10943-014-9992-2

Vincensi, B. B. (2019). Interconnections : Spirituality, Spiritual Care, and Patient - Centered Care. https://doi.org/10.4103/apjon.apjon

Waltz, C. F., Strickland, O. L., \& Lenz, E. R. (2010). Measurement in nursing and health research: Fourth edition. https://books.google.com.sa/books?id=1xAdjkR14ocC

Wardaningsih, S., \& Junita, A. P. (2021). Nurse's experiences in implementing an islamic care nursing practice in sharia-based hospital Yogyakarta: A 
phenomenological study. Open Access Macedonian Journal of Medical Sciences, 9, 182-188. https://doi.org/10.3889/oamjms.2021.5814

Warto, W. (2019). Ibadah Dan Kesehatan Dalam Perspektif Islam Dan Sains. Rausyan Fikr: Jurnal Pemikiran Dan Pencerahan, 15(2), 105-121. https://doi.org/10.31000/rf.v15i2.1809

Z, D., \& Avianti, N. (2017). Spiritual Emotional Freedom Technique Decreasing Stress on Patients With Cervical Cancer. Jurnal NERS, 9(1), 91. https://doi.org/10.20473/jn.v9i1.3233

Zaly, N. W. (2020). Seminar dan workshop pemenuhan kebutuhan spiritual pasien : panduan ibadah ketika sakit. Jurnal Masyarakat Mandiri, 4(4), 646-654. http://journal.ummat.ac.id/index.php/jmm 